\title{
Vegetation Cover and Forb Responses to Cattle Exclusion: Implications for Pronghorn
}

\author{
Matthew R. Loeser, ${ }^{1}$ Sharon D. Mezulis, ${ }^{2}$ Thomas D. Sisk, ${ }^{3}$ \\ and Tad C. Theimer ${ }^{4}$ \\ Authors are ${ }^{1}$ Graduate Research Assistant and ${ }^{4}$ Associate Professor, Department of Biological Sciences, \\ Northern Arizona University, Box 5640, Flagstaff, AZ 86011; and ${ }^{2}$ Research Assistant and ${ }^{3}$ Associate Professor, \\ Center for Environmental Sciences and Education, Northern Arizona University, Box 5694, Flagstaff, AZ 86011.
}

\begin{abstract}
Cattle grazing is often implicated as a factor that reduces vegetative cover and the abundance of important forage plants for wildlife. Recent declines in northern Arizona populations of pronghorn (Antilocapra americana Ord) have focused public and scientific attention on the factors contributing to low fawn recruitment and the potential benefits of cattle removal. To further understand the effects of cattle grazing, we studied the potential hiding cover provided by standing live and dead herbaceous matter as well as forb richness and canopy cover following 5 years of cattle removal. Cattle removal increased horizontal hiding cover by $8 \%$ at a distance of $5 \mathrm{~m}(P=0.025)$, but had no statistically significant effect on the potential hiding cover at distances of $10 \mathrm{~m}$ $(P=0.105)$ or $25 \mathrm{~m}(P=0.746)$. Forb species richness was $16 \%$ lower in exclosures than in an adjacent grazed pasture in 2001 $(P=0.036)$, but no differences were observed in $2002(P=0.636)$. The canopy cover of forbs was generally unaffected by cattle removal. These results suggest that curtailing or removing cattle is unlikely, by itself, to lead to rapid improvements in the hiding cover or forb availability for pronghorn on similar rangelands in northern Arizona. In this region, where immediate improvements in fawn survival and recruitment are important to population persistence, additional management actions should be considered.
\end{abstract}

\section{Resumen}

El apacentamiento frecuentemente es considerado como factor reductor de la cobertura vegetal y de la abundancia de importantes plantas forrajeras para la fauna. Las recientes disminuciones de poblaciones de berrendo (Antilocapra americana Ord) en el norte de Arizona han llamado la atención del público e investigadores en los factores que contribuyen a la baja población cervatillos y los beneficios potenciales de la remoción del ganado. A fin de entender más el efecto del apacentamiento del ganado, estudiamos la cobertura de protección potencial suministrada por la biomasa en pie y el material herbáceo muerto así como la riqueza de hierbas y cobertura de copa cinco años después de removido el ganado. La remoción del ganado incremento la cobertura horizontal de protección en $8 \%$ a una distancia de $5 \mathrm{~m}(P=0.025)$, pero no presentó diferencia estadística significativa a distancias de $10 \mathrm{~m}(P=0.105)$ o $25 \mathrm{~m}(P=0.746)$. En 2001 , la riqueza de especies herbáceas fue $16 \%$ inferior dentro de exclusiones que en las áreas adyacentes apacentadas $(P=0.036)$, pero en 2002 no se observaron diferencias $(P=0.636)$. La cobertura de copa generalmente no fue afectada por la remoción del ganado. Los resultados sugieren que exclusión o eliminación del ganado, por si misma, es poco probable que conduzca a un rápido mejoramiento de la cobertura de protección o disponibilidad de hierbas para el berrendo en tierras semajantes de pastizal del noreste de Arizona. En esta región, donde una mejoría inmediata de la supervivencia de cervatillos e incremento de su población son importantes para la persistencia de la población, acciones de manejo adicionales deben ser consideradas.

Key Words: Arizona grassland, grazing, horizontal cover, plant composition, plant cover, semiarid grassland

\section{INTRODUCTION}

Historical accounts from the 1850s suggest that pronghorn were relatively common throughout grasslands of northern Arizona, but by the 1920s pronghorn numbers were greatly reduced (Neff and Woolsey 1979). Populations recovered in

This study has been funded by the Ecological Restoration Institute of Northern Arizona University, the Merriam-Powell Center for Environmental Research, and the Coconino National Forest, US Department of Agriculture Forest Service.

Correspondence: Matthew R. Loeser, Center for Environmental Sciences and Education, Northern Arizona University, Box 5694, Flagstaff, AZ 86011. Email: Matthew.Loeser@ nau.edu

Manuscript received 23 October 2003; manuscript accepted 3 December 2004. the following 3 decades, but since 1950 some populations have again shown a steady decline. The disjunct pronghorn herd on Anderson Mesa, a semiarid, high-elevation grassland southwest of Flagstaff, Arizona, was estimated at 2200 in the 1930s and 1940s, making it the largest herd in the state (Neff and Woolsey 1979). The Arizona Game \& Fish Department (2002) estimated that the population had declined to 280 in 2000. Although this reduction was due in part to a severe blizzard in the 1960s, the lack of recovery following that event and subsequent population declines have been attributed primarily to decreased fawn recruitment (Neff and Woolsey 1979; Neff et al. 1985).

Several mechanisms have been hypothesized for low fawn recruitment (Beale and Smith 1973; Neff and Woolsey 1979; Neff et al. 1985; Ockenfels et al. 1992; Yoakum 2002), 
including increased predation, nutritional deficiencies of does or fawns, increased human disturbance, and disease. Predation by coyotes (Canis latrans Say), bobcats (Lynx rufus Schreber), and other predators is an important mortality factor for pronghorn fawns (Beale and Smith 1973; Neff and Woolsey 1979; Barrett 1984; Neff et al. 1985). Because predator avoidance appears to be the primary defensive strategy of fawns (Fichter 1974; Byers and Byers 1983), Barrett (1984) argued that inadequate cover to escape detection by predators may underlie widespread decreases in fawn recruitment.

Fawn recruitment is also affected by the availability and nutritional quality of forage in the diet of females. Forbs are a major part of the pronghorn's diet in grassland and shrubsteppe biomes during spring and summer, and are important because of their high nutrient and water content (Yoakum and O'Gara 2000). Likewise, pronghorn have been reported to reach their highest concentrations on ranges with abundant surface water and a large forb component (Alldredge et al. 1991). Pronghorn in Arizona are deficient in selenium and copper, perhaps due to decreased quality or availability of preferred forage species (Heffelfinger et al. 1999). Similar mineral deficiencies have been linked to reproductive failures in domestic ruminants (Robbins 1993) and may play a role in pronghorn reproduction.

Cattle grazing is known to reduce standing plant biomass, potentially reducing cover and forage availability for pronghorn (Howard et al. 1990; Ockenfels et al. 1992; Yoakum 1994). Long-term effects of livestock grazing may also include increased shrub density (Archer 1994), and intensive cattle grazing before or during fawning season may displace females, further depressing population growth rates (Yoakum and O'Gara 2000). On the basis of research conducted in Arizona, Ockenfels et al. (1992) recommended deferment of cattle grazing until after fawning, to conserve sufficient hiding cover for newborn pronghorn. In deferred grazing programs, excessive grazing during other times of the year could continue to degrade grasslands, reducing hiding cover or forage availability, thereby further stressing pronghorn. Contrary to conclusions that cattle grazing necessarily degrades pronghorn habitat, cattle can increase some forb densities (Brady et al. 1989) and grassland production (Loeser et al. 2004). From a historical perspective, Kindschy et al. (1978) suggested that the grassland habitats preferred by pronghorn might have been maintained through seasonal grazing by wildlife and by intermittent fire. From this perspective, managed cattle grazing might be compatible with, or even beneficial to, pronghorn habitat management.

This lack of consensus has led to discord, conflict, and litigation regarding the appropriate management of livestock grazing on Anderson Mesa and of pronghorn, a management indicator species for the US Forest Service. As land and wildlife managers respond to the challenge of conserving this population of pronghorn, we evaluated the effectiveness of one potential management action, cattle removal. We addressed two aspects of pronghorn habitat quality: 1) Does the exclusion of cattle increase potential fawn hiding cover?; and 2) does this exclusion of cattle increase species richness and cover of forbs, which are important forage plants for pronghorn?

\section{METHODS}

\section{Site Description}

Anderson Mesa is an uplifted mesa of volcanic origin occupying 106000 ha southeast of Flagstaff, Arizona. In 1997, we established a study site on the northern end of Anderson Mesa at the transition zone of grassland and woodland (lat $34^{\circ} 59^{\prime} 03^{\prime \prime} \mathrm{N}$, long $\left.111^{\circ} 26^{\prime} 30^{\prime \prime} \mathrm{W}\right)$. The mean annual precipitation for the study site is $500 \pm 100 \mathrm{~mm}$; however, this study occurred during below-normal precipitation conditions. Precipitation was $31 \%$ below average in 2001 and $55 \%$ below average in 2002 when data presented here were collected (Western Region Climate Center 2003). The soils are classified as mollisols dominated by shrink-swell clays with basalt cobbles throughout. The primary vegetation association is semiarid grassland, but the area includes large areas of juniper (Juniperus monosperma [Engelm.] Sarg.) woodlands and ponderosa pine (Pinus ponderosa P. \& C. Lawson) forests. The most abundant plant species include western wheatgrass (Pascopyrum smithii [Rydb.] A. Löve), squirreltail (Elymus elymoides [Raf.] Swezeyi), and Carruth's sagewort (Artemisia carruthii Wood ex. Carruth.).

Within a 320-ha pasture, 3 1-ha cattle exclosures were erected as part of a more elaborate experimental effort (see Sisk et al. 1999). Exclosures are located at least $200 \mathrm{~m}$ from one another. The grazed pasture had an average grazing rate of 1 cow-calf pair ha ${ }^{-1}$ for 20 days year ${ }^{-1}$ for approximately 15 years before the initiation of this study. Lower-density, season-long livestock grazing was applied as far back as the late 19th century and included sheep and cattle (K. Metzger, personal communication, 2001). Our exclosures did not exclude grazing by elk, deer, or pronghorn, and surveys of fecal pellet groups, lumped across wild ungulates, showed low-to-moderate wildlife usage (livestock exclosures $=0.9 \pm 0.2$ pellet groups $/ 10 \mathrm{~m}^{2}$; grazed pasture $=0.9 \pm 0.3$ pellet groups $/ 10$ $\mathrm{m}^{2}$; M. Loeser, unpublished data, 2002).

\section{Hiding Cover Estimates With Visual Obstruction}

In late spring of 2002, 5 years after initiating the cattle exclosure treatment, we estimated horizontal cover (Bonham 1989) as a measure of potential bed-site hiding cover for pronghorn fawns in cattle exclosures and the adjacent grazed pasture. We randomly located 5 phototransects in each of 3 cattle exclosure plots, and in matched plots on adjacent, grazed land $(n=3)$. The random location of transects was determined by throwing a flagged stick blindly over the shoulder of the observer. Although pronghorn are unlikely to choose bed sites randomly, we assumed that vegetative cover at random locations would be indicative of the cover available in nonrandomly selected bed sites. This assumption is likely to be true at our site, which exhibits little variation in fine-scale relief, aspect, or topography. We collected measurements during late May and early June to coincide with the period of pronghorn fawning. We took digital photos from a $50-\mathrm{cm}$ stand (estimated eye level of a coyote) of a $15 \mathrm{~cm} \times 20 \mathrm{~cm}$ rectangular target staked vertically in the ground. The target size was estimated roughly as the size of a prostrate pronghorn fawn. A digital camera with a maximum zoom capacity of $\times 4$ was used for photographing.

We quantified the proportion of a target that was obstructed by herbaceous vegetation at distances of 5,10 , and $25 \mathrm{~m}$. To 


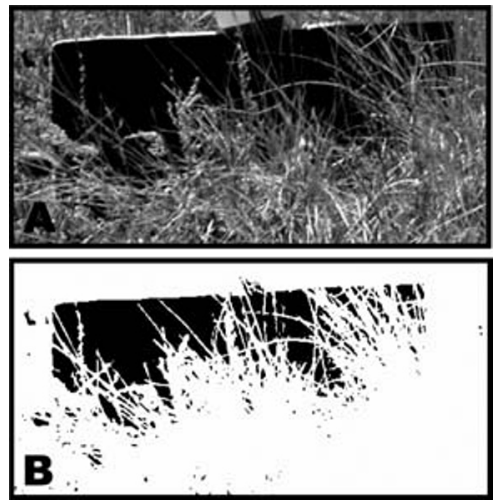

Figure 1. Digital photographs of a fawn-sized target $(15 \mathrm{~cm} \times 20 \mathrm{~cm})$ were taken from a height of $50 \mathrm{~cm}$ and converted to black and white images. Each image was clipped to the dimensions of the target and we calculated the proportion of obstruction by herbaceous vegetation.

quantify horizontal cover in the digital photos, we used a computer software program that quantified pixels by colors (G-Pix; Roset 1997; Paruelo et al. 2000). This method uses an algorithm that detects changes in contrast, which in this case occurs when plants appear in front of a solid black target. Digital photos $\left(4 \times 10^{4}\right.$ pixels $)$ were cropped to the dimensions of the target, converted to gray-scale and then black and white, and converted to a TGA file format (Fig. 1). The G-Pix program allowed us to separate obstructing vegetation (white pixels) from the target (black pixels). The percentage of target covered by plants was calculated by dividing the number of white pixels by the total number of pixels and multiplying by 100 .

We calculated an average coverage value for each plot, then tested normality assumptions with a Shapiro-Wilks $W$ test (Sokal and Rohlf 1995). These data met normality assumptions so we then tested for significant differences by treatment (cattle exclosure vs. grazed area) using a $t$ test blocked by the pairings of cattle exclosure and adjacent grazed areas; an alpha of $P<$ 0.05 was used in all statistical tests (Sokal and Rohlf 1995).

\section{Forb Richness and Cover}

To determine the species richness of forbs, an important part of the diet of pronghorn, we conducted surveys in mid-summer 2001 and 2002, prior to grazing by cattle, and thereby maximizing our ability to detect the senescing early-season forbs and germinating late-season forbs. We established a permanent $20 \mathrm{~m} \times 50 \mathrm{~m}$ modified-Whittaker survey area in each plot (3 in cattle exclosures and 3 in grazed areas). We inventoried plant species in nested subplots of 1,10 , and $100 \mathrm{~m}^{2}$ and estimated species richness as described in Stohlgren et al. (1995, 1997). We estimated the similarity of plant communities among treatments using Jaccard's coefficient (signified as J; Krebs 1989), where a value of $J=1.0$ represents complete overlap of species between two plots. We then averaged $J$ for each treatment within each year and generated a corrected species-area curve as demonstrated by Stohlgren et al. (1997), and estimated species richness for an area of $10000 \mathrm{~m}^{2}$, the size of our individual exclosures. We used a $t$ test, blocked by paired plots, to determine significant effects of treatment within year.

In addition, we measured the percentage of canopy cover of forbs in the $101-\mathrm{m}^{2}$ subplots located within each modified-

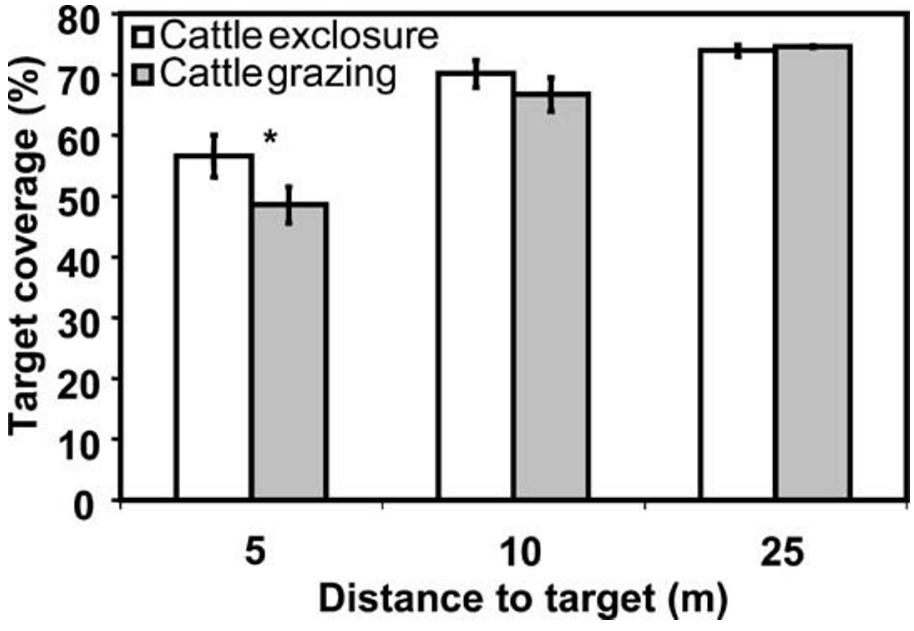

Figure 2. Horizontal cover estimates for grazed and ungrazed plots, measured as the percentage of targets obstructed by herbaceous plants between a digital camera and a fawn-sized target at distances of 5,10 , and $25 \mathrm{~m}$ (mean $\pm \mathrm{SE}$ ). Ungrazed plots had $8 \%$ more cover than grazed plots at a distance of $5 \mathrm{~m}(t=6.170, P=0.025)$, but no statistically significant differences were measured at either 10 or $25 \mathrm{~m}(10 \mathrm{~m}$ : $t=2.835, P=0.105 ; 25 \mathrm{~m}: t=-0.371, P=0.746) .{ }^{*}$ indicates a statistically significant $(P<0.05)$ difference between cattle exclosure and adjacent grazed plots.

Whittaker plot, using a pin frame (Mueller-Dombois and Ellenberg 1974; Kent and Coker 1992). We placed a pin $($ diameter $=0.5 \mathrm{~cm})$ through the frame 50 times for each $1-\mathrm{m}^{2}$ subplot and recorded all basal and foliar contacts with the pin. Canopy cover was estimated as the number of contacts with forbs divided by 50 . The pin frame method is robust to multiple observers and performs well in low-growing vegetation (Kent and Coker 1992). We used a $t$ test blocked in accordance with the paired treatment design to determine statistical significance.

\section{RESULTS}

\section{Hiding Cover Estimates With Visual Obstruction}

We found that the removal of cattle grazing led to $8 \%$ greater hiding cover at the distance of $5 \mathrm{~m}$ (Fig. 2, $t=6.170$, $P=0.025)$. However, cattle exclosures showed no statistically significant effect at either $10 \mathrm{~m}(t=2.835, P=0.105)$ or $25 \mathrm{~m}$ $(t=-0.371, P=0.746)$.

\section{Forb Richness and Cover}

Estimated forb richness per hectare was 16\% lower in livestock exclosures than the adjacent grazed pasture in 2001 (Table 1, $t=-0.515, P=0.036)$, but no difference was found in 2002 (Table $1, t=0.553, P=0.636$ ). In 2001, the following perennial forbs were documented for the grazed pasture, but not the livestock exclosure: fineleaf hymenopappus (Hymenopappus filifolius Hook.), Nevada biscuitroot (Lomatium nevadense [S. Wats.] Coult. \& Rose), Woodhouse's phlox (Phlox speciosa Pursh ssp. woodhousei [Torr. ex Gray] Wherry), slender cinquefoil (Potentilla gracilis Dougl. Ex Hook.), and Fendler's pennycress (Thlaspi montanum L. var. fendleri [Gray] P. Holmgren). 
Table 1. Forb species richness (mean \pm SE) and Jaccard's $(J)$ coefficient of similarity (mean \pm SE) for cattle exclosures and adjacent grazed areas in 2001 and 2002. Species-area equations were used to estimate forb richness for 1 ha, using data from modifiedWhittaker plots (Stohlgren et al. 1995).

\begin{tabular}{|c|c|c|c|c|}
\hline Year & Treatment & Species-area Equation & Mean $J$ & $\begin{array}{c}\text { Mean } \\
\text { spp./1 ha }\end{array}$ \\
\hline \multirow[t]{2}{*}{2001} & $\begin{array}{l}\text { Cattle } \\
\text { Exclosure }\end{array}$ & $\begin{aligned} y= & (6.928 / J) \log (\text { area }) \\
& +4.3458\end{aligned}$ & $0.590 \pm 0.038$ & $51.3 \pm 3.0$ \\
\hline & $\begin{array}{l}\text { Cattle } \\
\text { Grazing }\end{array}$ & $\begin{aligned} y= & (7.710 / J) \log (\text { area }) \\
& +5.5735\end{aligned}$ & $0.570 \pm 0.056$ & $59.7 \pm 1.4$ \\
\hline \multirow[t]{2}{*}{2002} & $\begin{array}{l}\text { Cattle } \\
\text { Exclosure }\end{array}$ & $\begin{aligned} y= & (5.246 / J) \log (\text { area }) \\
& +2.7101\end{aligned}$ & $0.499 \pm 0.020$ & $44.7 \pm 1.5$ \\
\hline & $\begin{array}{l}\text { Cattle } \\
\text { Grazing }\end{array}$ & $\begin{aligned} y= & (5.101 / J) \log (\text { area }) \\
& +3.4493\end{aligned}$ & $0.510 \pm 0.010$ & $43.4 \pm 0.9$ \\
\hline
\end{tabular}

${ }^{1}$ Indicates a significant $(P<0.05)$ difference between cattle exclosure and adjacent grazed plots for that year.

Forbs comprised a mean canopy cover, in absolute percentages, of approximately 20\% in 2001 and 2002, regardless of treatment. Grazing treatments yielded no statistically significant differences in the percentage of canopy cover of forbs (2001: $t=0.388, P=0.736$; 2002: $t=0.445, P=0.700)$. In 2001, the canopy cover mean and standard error for the exclosures was $22.5 \% \pm 2.1 \%$ and $20.9 \% \pm 4.4 \%$ for the grazed pasture. In 2002, the forb canopy cover for the exclosures was $21.3 \% \pm 2.4 \%$ and $18.6 \% \pm 3.9 \%$ for the grazed pasture.

\section{DISCUSSION}

We found that horizontal plant cover in areas where cattle grazing was experimentally excluded was increased by $8 \%$ at distances of $5 \mathrm{~m}$, but showed no statistically significant effect at distances of $10 \mathrm{~m}$ or $25 \mathrm{~m}$. Although the critical components necessary for adequate hiding cover for pronghorn are difficult to define, our results raise doubts that the removal of cattle as a management strategy would yield meaningful short-term benefits in fawn hiding cover on Anderson Mesa. We urge cautious interpretation of these results, in part because bed-site selection by fawns apparently represents a trade-off between concealment and the ability to detect predators at a distance (Barrett 1981; Canon and Bryant 1997). This behavior may lead to different site selection preferences in different locations. In the absence of detailed understanding of the fawning behavior of pronghorn females on Anderson Mesa, many previous studies (Howard et al. 1990; Ockenfels et al. 1992; Yoakum 1994, 2002) have addressed the hypothesized negative effects of cattle-grazing on pronghorn fawn bed-site quality, focusing on changes in the amount of cover available. Studies in habitats dominated by shrub-steppe vegetation documented that fawn bed sites were associated with greater shrub and overall vegetation cover (Autenrieth 1976; Alldredge et al. 1991), whereas studies in open, arid grasslands showed that shrub cover was negatively associated with bed-site selection (Barrett 1984; Canon and Bryant 1997). Furthermore, fawn bedsites are not selected randomly by pronghorn females, whereas our hiding cover measurements were made at randomly selected points in cattle-removal and cattle-grazed plots. Unless cattle preferentially graze or avoid microsites selected as fawning areas (an unlikely case for which no data are available) we believe that the availability of horizontal cover, as we measured it, should be indicative of cover available at fawning sites.

We found mixed evidence that species richness of forbs responded to 5 years of cattle removal. Our species-area equations, based on the nested subplots of the modifiedWhittaker design, estimated $16 \%$ fewer forb species in cattle exclosures than in adjacent grazed pasture in 2001. However, in 2002, treatments showed nearly identical estimates of forb richness. This result suggests either a transitory effect of cattle exclosures on forb richness or the effects of interannual variation in precipitation. The 2002 growing season in northern Arizona was noteworthy in that it fell within a period of record drought (Western Regional Climate Center 2003). Regardless of the reason for the interannual variation we detected, in neither year was forb richness greater in areas where cattle had been excluded, indicating that cattle exclusion did not increase forb diversity. Canopy cover by forbs did not differ significantly between cattle exclosures and adjacent grazed areas in either year, although both years showed marginally greater canopy cover in exclosures.

We propose three possible interpretations for the failure of cattle exclusion to increase forb richness and cover. First, ground disturbance can benefit forbs (e.g., Gillen et al. 1991; Fahnestock and Knapp 1994) and the soils of Anderson Mesa are routinely disturbed by shrink-swell events triggered by seasonal droughts followed by intense summer rains. Second, the grassland community we studied may be relatively stable and resilient in response to the level of cattle grazing currently practiced. This may have been an attribute of the original grassland community of the area or may reflect a community altered by over a century of livestock grazing that is now dominated by species adapted to this type of disturbance. Finally, the plant community may be slow to respond to changing grazing pressures, such that effects of cattle removal take longer than 5 years to reflect significant change. The rate of recovery after cattle removal is strongly dependent on climate, and under different weather patterns from those experienced during this study, these grasslands could show stronger or weaker effects of removal. In the short term, however, this study demonstrates that under current conditions, cattle exclusion alone is unlikely to increase forb richness or forb cover. Other studies of semiarid grasslands demonstrate that generalities about the effects of cattle removal on forb species are complicated. Stohlgren et al. (1999) found greater forb cover in grazed plots than in ungrazed plots in 4 of 9 Rocky Mountain sites, but the pattern was reversed in 2 other sites, and highly variable in the remaining 3 sites. The forb density of short-grass steppe responded positively to cattle removal (Milchunas et al. 1989), whereas Brady et al. (1989) found no effect of cattle removal on forb cover in a semidesert. The mixed effects of grazing on forbs is certainly influenced by differences in site productivity, plant community composition, grazing history, soil characteristics, and local weather patterns.

The population viability of pronghorn on Anderson Mesa ultimately depends on a suite of interacting factors in addition to fawn cover, some of which may be affected by cattle. Cattle grazing has been shown to negatively affect forage for pronghorn (Howard et al. 1990; Yoakum 1994), but Kindschy et al. 
(1978) found grazing to improve vegetation communities for pronghorn. Management strategies proposed by US Forest Service for Anderson Mesa include removal or curtailment of cattle grazing in an effort to increase the amount of hiding cover for pronghorn fawns and the availability of forbs, and thereby improve the overall range quality. Although grazing before or during the fawning period would reduce vegetation cover, our results suggest that year-round removal of cattle from the grasslands of Anderson Mesa is unlikely to yield meaningful, shortterm improvements in these habitat parameters. Cattle removal could lead to long-term improvements in pronghorn habitat if these grasslands are simply slow to recover after cattle removal or if the 5 years of our study were not representative of responses under more typical conditions.

\section{ACKNOWLEDGMENTS}

We gratefully acknowledge the assistance of L. Taylor, R. Rieder, and Z. Bayham in collecting these data. In addition we thank the Diablo Trust, Flying M Ranch, the Peaks and Mormon Lake Districts of the Coconino National Forest, and the Arizona Game and Fish Department for their participation in this collaborative research effort. This manuscript has benefited from the critical reviews of $\mathrm{M}$. McClaran and 2 anonymous reviewers.

\section{LITERATURE CITED}

Alldredge, A. W., R. D. Deblinger, and J. Peterson. 1991. Birth and fawn bed site selection by pronghorn in a sagebrush-steppe community. Journal of Wildlife Management 55:222-227.

ARCHER, S. 1994. Woody plant encroachment into southwestern grasslands and savannas: Rates, patterns, and proximate causes. In: M. Vavra, W. Laycock, and R. Pieper [eds.]. Ecological implications of livestock herbivory in the West. Denver, C0: Society of Range Management. p 13-68.

Arizona Game and Fish Department. 2002. Anderson Mesa herd pronghorn operational plan. Available at: http://www.gf.state.az.us/pdfs/w_c/research/ antelope_study_plan.pdf. Accessed 1 June 2004.

AutenRIETH, R. E. 1976. A study of birth sites selected by pronghorn does and the bed sites of fawns. Proceedings of the Pronghorn Antelope Workshop 7:127-134.

BARRETT, M. W. 1981. Environmental characteristics and functional significance of pronghorn fawn bedding sites in Alberta. Journal of Wildlife Management 45:120-131.

BARRett, M. W. 1984. Movements, habitat use, and predation on pronghorn fawns in Alberta. Journal of Wildlife Management 48:542-550.

Beale, D. M., And A. D. Smith. 1973. Mortality of pronghorn antelope fawns in western Utah. Journal of Wildlife Management 37:343-352.

Bonham, C. 1989. Measurements for terrestrial vegetation. New York, NY: John Wiley and Sons. $352 \mathrm{p}$.

Brady, W. W., M. R. Stromberg, E. F. Aldon, C. D. Bonham, and S. H. Henry. 1989. Response of a semidesert grassland to 16 years of rest from grazing. Journal of Range Management 42:284-288.

BYERS, J. A., AND K. Z. BYERS. 1983. Do pronghorn mothers reveal the locations of their fawns? Behavioral Ecology and Sociobiology 13:147-156.

Canon, S. K., and F. C. Bryant. 1997. Bed-site characteristics of pronghorn fawns. Journal of Wildlife Management 61:1134-1141.

Fahnestock, J. T., AND A. K. KnapP. 1994. Plant responses to selective grazing by bison: interactions between light, herbivory and water stress. Vegetatio 115: 123-131.

FICHTER, E. 1974. On the bedding behavior of pronghorn fawns. In: V. Geist and F. Walther [eds.]. The behavior of ungulates and its relation to management. International Union for the Conservation of Nature and Natural Resources Publication Serial 24, Morges, Switzerland. p 352-355.
Gillen, R. L., F. T. McCollum, M. E. Hodges, J. E. Brummer, and K. W. Tate. 1991. Plant community responses to short duration grazing in tallgrass prairie. Journal of Range Management 44:124-128.

Heffelfinger, J. R., R. J. Olding, T. H. Noon, M. R. Shupe, and D. P. Betzer. 1999. Copper/selenium levels and occurrence of bluetongue virus in Arizona pronghorn. Proceedings of the Pronghorn Antelope Workshop 18:32-42.

Howard, V. W., J. L. Holechek, R. D. Pieper, L. Green-Hamond, M. Cardenas, and S. L. BEASOM. 1990. Habitat requirements for pronghorn on rangelands impacted by livestock and net wire in east central New Mexico. New Mexico State University Agriculture Experiment Station Bulletin 750. Las Cruces, NM. 48 p.

Kent, M., ANd P. Coker. 1992. Vegetation description and analysis: A practical approach. Boca Raton, FL: CRC Press. 363 p.

KInDSCHY, R. R., C. SundSTROM, AND J. YoAKUM. 1978. Range/wildlife interrelationships-pronghorn antelope. Proceedings of the Pronghorn Antelope Workshop 8:216-269.

KREBS, C. J. 1989. Ecological methodology. New York, NY: Harper and Row. 654 p. Loeser, M. R., T. E. Crews, ANd T. D. SISK. 2004. Defoliation increased aboveground productivity in a semi-arid grassland. Journal of Range Management 57:442-447.

Milchunas, D. G., W. K. Lauenroth, P. L. Chapman, and M. K. Kazempour. 1989. Effects of grazing, topography, and precipitation on the structure of a semiarid grassland. Vegetatio 80:11-23.

Mueller-Dombois, D., and H. Ellenberg. 1974. Aims and methods in vegetation ecology. New York, NY: John Wiley \& Sons. 547 p.

Neff, D. J., R. H. Smith, and N. G. Woolsey. 1985. Pronghorn antelope mortality study: final report. Federal Aid in Wildlife W-78-R, Work Plan 2. Arizona Game and Fish Department. Phoenix, AZ. 22 p.

NefF, D. J., AND N. G. Woolsey. 1979. Effect of predation by coyotes on survival of antelope fawns on Anderson Mesa. Federal Aid in Wildlife W-78-R. Special Report 8, Arizona Game and Fish Department. Phoenix, AZ. 36 p.

OCKenfels, R. A., C. L. Dorothy, AND J. D. KIRKLAND. 1992. Mortality and home range of pronghorn fawns in central Arizona. Proceedings of the Pronghorn Antelope Workshop 15:78-92.

Paruelo, J. M., W. K. Lauenroth, and P. A. Roset. 2000. Estimating aboveground plant biomass using a photographic technique. Journal of Range Management 53:190-193.

RoBBins, C. 1993. Wildlife feeding and nutrition. New York, NY: Academic Press. $325 \mathrm{p}$.

ROSET, P. 1997. G-pix software. University of Buenos Aires.

Sisk, T. D., T. E. Crews, R. T. Elsfeldt, M. King, and E. Stanley. 1999. Assessing impacts of alternative livestock management practices: raging debates and a role for science. In: C. van Riper III and M.A. Stuart [Eds.]. Fourth Biennial Conference of Research on the Colorado Plateau; 15-18 September 1997; Flagstaff, AZ. Flagstaff, AZ: U.S. Geological Survey. p 89-103.

SoKal, R. R., AND F. J. Rohlf. 1995. Biometry. New York, NY: W.H. Freeman and Co. $859 \mathrm{p}$

Stohlgren, T. J., G. W. Chong, M. A. Kalkhan, and L. D. Schell. 1997. Rapid assessment of plant diversity patterns: a methodology for landscapes. Environmental Monitoring and Assessment 48:25-43.

Stohlgren, T. J., M. B. Falkner, and L. D. Schell. 1995. A modified-Whittaker nested vegetation sampling method. Vegetatio 117:113-121.

Stohlgren, T. J., L. D. Schell, and B. Vanden Heuvel. 1999. How grazing and soil quality affect native and exotic plant diversity in rocky mountain grasslands. Ecological Applications 9:45-64.

Western Regional Climate Center. 2003. Arizona climate records. Available at: http://www.wrcc.dri.edu. Accessed 1 December 2003.

Yoакum, J. D. 1994. Water requirements for pronghorn. Proceedings of the Pronghorn Antelope Workshop 16:143-157.

YоАKUM, J. D. 2002. An assessment of Pronghorn populations and habitat status on Anderson Mesa, Arizona: 2001-2002. A report submitted to the Arizona Wildlife Federation. Phoenix, AZ. 122 p.

Yoakum, J., and B. O'Gara. 2000. Pronghorn. In: S. Demarais and P. Krausman [eds.]. Ecology and management of large mammals in North America. Upper Saddle River, NJ: Prentice Hall. p 559-577. 